\title{
REVIEW
}

\section{Advances in eucalypt research in China}

\author{
Yaojian XIE (凶), Roger J. ARNOLD, Zhihua WU, Shuaifei CHEN, Apeng DU, Jianzhong LUO
}

China Eucalypt Research Centre, Chinese Academy of Forestry, Zhanjiang 524022, China

\begin{abstract}
Eucalypt plantations in China currently exceed 4.5 $\mathrm{Mhm}^{2}$, and this country has the third largest area of such plantations after India and Brazil. China's eucalypt industry now comprises a complex, multifaceted industry including seedling propagation, fertilizer production and supply, plantation silviculture, harvesting and transport, wood processing for products including lumber, pulp and paper, and wood-based panels, as well as bioenergy production and various forest byproducts and non-wood forest products. In 2015, the combined value of output of this whole industry was around 300 billion CNY. Chinese research and development (R\&D) has been instrumental in supporting growth and development across the whole breadth of the country's eucalypt industry. In this report, recent advances in this $R \& D$ are reviewed under six key topics: (1) advanced propagation technology; (2) genetic resources and breeding; (3) targeted silviculture; (4) eucalypt disease and pest management; (5) enhancing plantation ecology and sustainability; and (6) wood processing and byproduct technology. $\mathrm{R} \& \mathrm{D}$ has greatly facilitated expansion and proliferation of all parts of China's eucalypt industry. This industry is now of major importance to China's economy; it involves tens of thousands of growers and companies that provide livelihoods for hundreds of thousands of people.
\end{abstract}

Keywords China Eucalypt Research Centre, timber production, tree improvement, silviculture, forest industry, Eucalyptus

\section{Introduction}

Eucalyptus species were first introduced to China in 1890 , initially to provide adaptable trees for use in amenity and ornamental plantings, such as those on farm boundaries, along roads and canals, around homes and public buildings and in agroforestry systems ${ }^{[1,2]}$. In the $1950 \mathrm{~s}$, large-area

Received April 7, 2017; accepted September 16, 2017

Correspondence: cercxieyj@163.com trial plantings were conducted in south-west Guangdong and southern Guangxi. Following from the success of these plantings for adaptation and yields of versatile timbers, eucalypts were soon promoted as a major afforestation tree species across southern China. Large scale expansion of eucalypt plantations through southern China started in earnest in the 1980s, and by the mid-1980s the area totaled over $450000 \mathrm{hm}^{2}$. Since then, genetic gains from tree improvement, advances in silviculture, buoyant and increasing demands for forest products and favorable government policies have worked together to foster rapid expansion of this resource. By the mid-1990s, the area had expanded to over $650000 \mathrm{hm}^{2\left[^{3}\right]}$.

Since the turn of the century, the eucalypt plantation area in China has increased even more rapidly, with the resource expanding to over 4.5 million $\mathrm{hm}^{2}$ by $2015^{[4]}$. This particularly rapid expansion over the last two decades can be attributed to a combination of factors including favorable government policies; forest land tenure reforms; strong and increasing demand for timber and fiber; increased grower recognition of profit potential from such plantations; major enhancements to productivity delivered by research and development (R\&D); and, a few large pulp and paper companies endeavoring to develop large areas of short-fibered, plantation-based pulpwood resources ${ }^{[3,5]}$.

In 2015, China's eucalypt plantations produced about 30 million $\mathrm{m}^{3}$ of wood, accounting for about $27 \%$ of the country's total annual domestic timber output ${ }^{[6]}$. These plantations thereby make a substantial contribution to safeguarding the security of China's wood supply. It is also noteworthy that this substantial production of raw material is part of a complete industry that includes everything from seedling propagation, fertilizer and chemical production and supply, pulp and paper manufacture, wood-based panel production, sawn timber production, biomass energy production and a range of non-wood forest products and byproducts. The total production value of this eucalypt industry in 2015 was estimated to have amounted to around 300 billion $\mathrm{CNY}^{[6]}$.

Today China's eucalypt plantation resource extends across 600 counties in 18 regions (including Taiwan) in 
southern China. Its distribution spans latitudes $18^{\circ}$ to $32^{\circ}$ $\mathrm{N}$, longitudes $100^{\circ}$ to $122^{\circ} \mathrm{E}$ and altitudes ranging from sea level to over $2000 \mathrm{~m}$. The regions with the largest eucalypt plantations areas in China are Guangxi and Guangdong, which have over 2 million and 1.3 million $\mathrm{hm}^{2}$, respectively, and together account for over $75 \%$ of region's total eucalypt area (Fig. 1). Mostly, selected clones of the hybrid Eucalyptus urophylla $\times$ E. grandis are grown, with smaller areas of E. camaldulensis, E. dunnii, E. globulus, E. maidenii (syn. E. globulus subsp. maidenii), E. pellita, E. saligna, E. smithii and E. tereticornis as well as hybrids of some of these species.

\section{Recent advances in eucalypt research}

The latest advances in research on commercial eucalypt genotypes in China are discussed below under six specific topics.

\subsection{Advanced propagation technology}

High level research on propagation and planting stock production technology for Eucalyptus conducted at South China Experimental Nursery (SCEN), China Eucalypt Research Centre (CERC), includes four key aspects (Fig. 2). The first covers research into vegetation propagation and mass multiplication of selected genotypes through tissue culture ${ }^{[7,8]}$. Using stem sections of E. urophylla $\times$ E. grandis as the explant tissue, adventitious buds and callus can now be induced with success rates of up to $84 \%$ and subsequent rooting rates of up to $92 \%{ }^{[9]}$.

The second key aspect is development of improved soilless growth media, which has involved improved processing and production technology for commercialscale planting-stock production. Investigations of the effects of growth media formulated with varying proportions of coconut fiber (coir), rice husk and sawdust on eucalypt stock survival rates, seedling form and quality indices and comprehensive costs have identified the optimal formula as coconut fiber, rice husk and sawdust in the ratio $2: 1: 4^{[10,11]}$. Other investigations into the effects of particles size found that media with particles under $0.5 \mathrm{~cm}$ are generally superior. Use of such soilless growth media in commercial nurseries for production of eucalypt planting stock, including seedlings, rooted cuttings and tissue culture plantlets, has already become a key technology in modern eucalypt nurseries and has replaced soil-based growth media ${ }^{[12]}$. Alternatives proposed previously, involving peat substrates, can have undesirable environmental impacts, as peat is a nonrenewable resource, and the Chinese government has banned peat extraction in order to protect wetlands. Therefore, SCEN produces commercial soilless substrates using local agricultural and forestry residues which are processed using composting and fermentation. This technology has now become mature and has been widely adopted by commercial nurseries.

The third key aspect covers development of superior container systems at SCEN for eucalypt propagation in China. Propagation of commercial eucalypt planting stock in southern China involves relative short growth cycles to produce plants $20-30 \mathrm{~cm}$ high without large root systems. To efficiently and economically produce plants that meet high quality standards, several kinds of propagation trays have been developed to support non-woven mesh propagation bags and the corresponding facilities. This technology has proven efficient and highly practical in

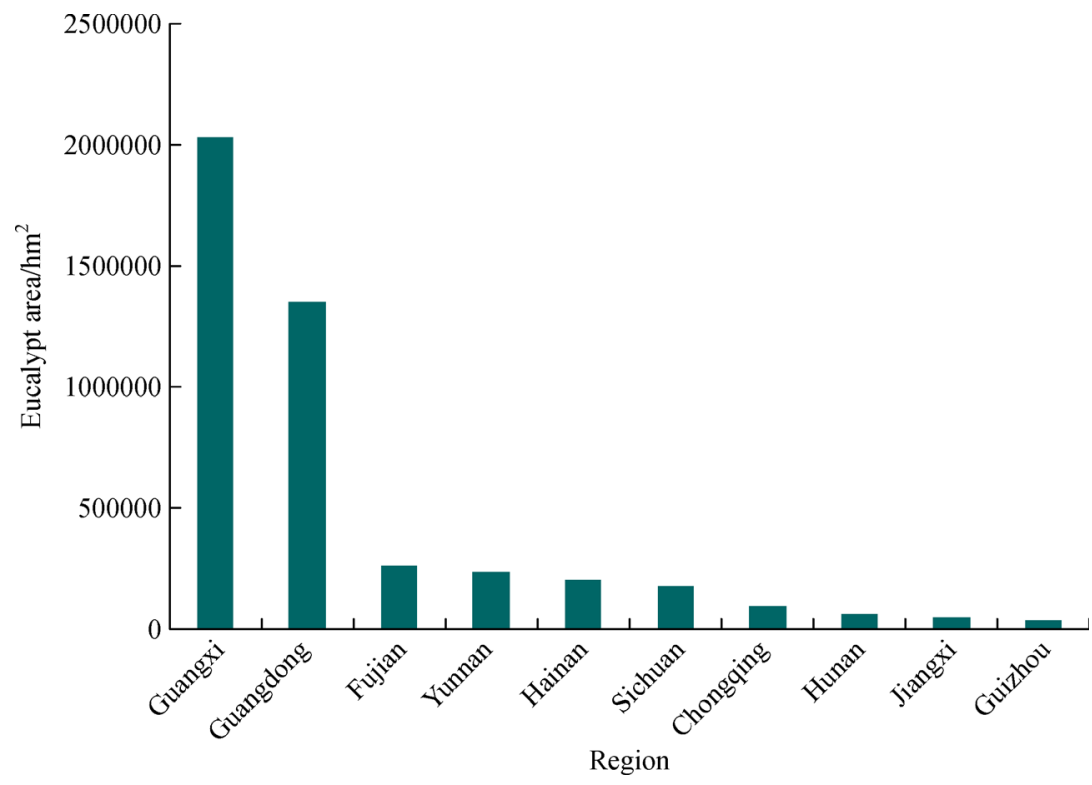

Fig. 1 Areas of eucalypt plantations in China 


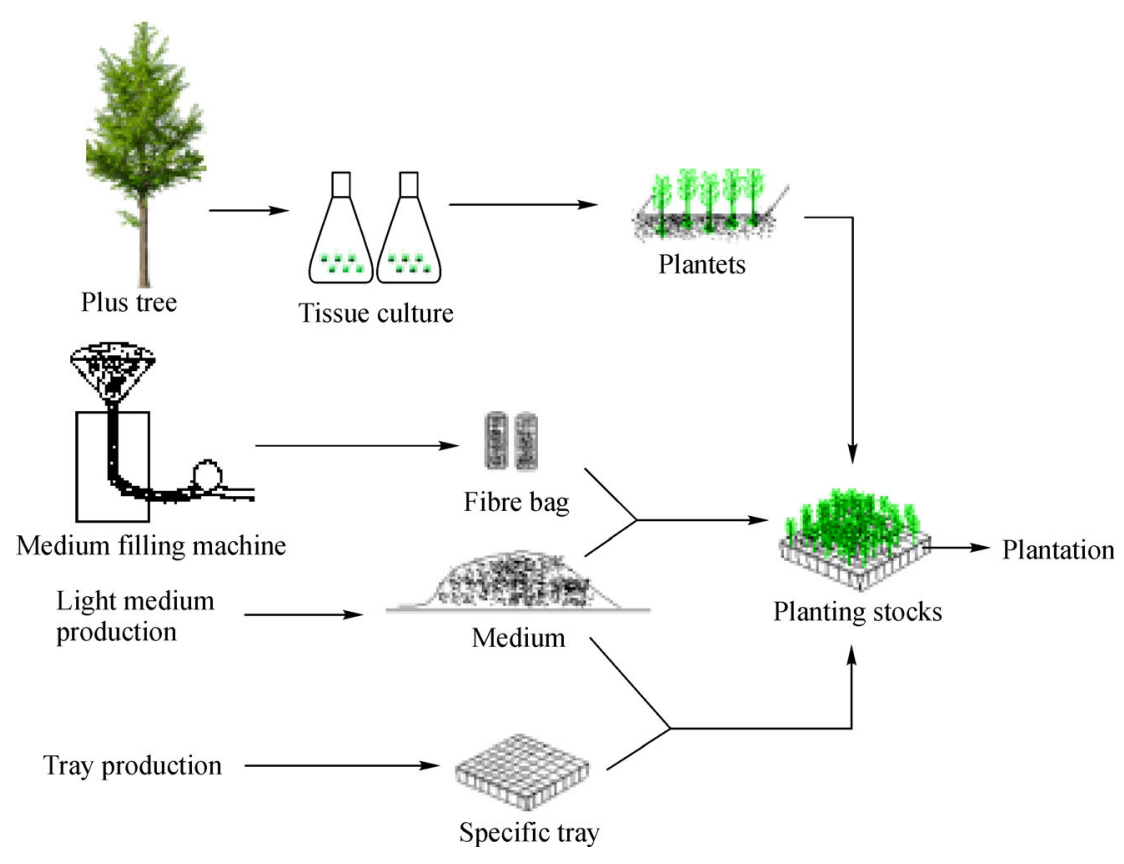

Fig. 2 Micropropagation and modern nursery technology for eucalyptus

commercial application, and has greatly facilitated seedling/propagule transportation. Applications for patents on this system have been submitted, and the technology is being adopted by commercial nurseries in China and elsewhere.

The fourth key aspect involves maintenance and nutrition of eucalypt plants in commercial nurseries. Fertilizers synthesized from biogas slurries have proved to significantly increase the height and diameter of eucalypt nursery stock, as well as chlorophyll content and leaf area, compared to control treatments ${ }^{[13]}$. Other investigations found significant differences between four special fertilizer formulations in growth, and root, leaf and stem biomass of propagules of the E. urophylla $\times$ E. grandis hybrid clone DH32-29; with a special slowrelease fertilizer proving optimal ${ }^{[14]}$. Investigation of the influence of nitrogen application methods on growth and chlorophyll content of E. urophylla seedlings demonstrated that exponential fertilization is superior to normal fertilization $^{[15]}$.

\subsection{Genetic resources and breeding}

Eucalypt species grown in Chinese plantations before 1980 were mostly of unknown genetic origin and history, and had not been subjected to formal genetic improvement ${ }^{[3]}$. Commencing from the early 1980s, a series of ChineseAustralian cooperative R\&D projects greatly accelerated the domestication and local development of improved eucalypts in $\mathrm{China}^{[3]}$. Such work identified E. camaldulensis, E. grandis, E. pellita E. tereticornis and E. urophylla, either as pure species or hybrids, as having the greatest economic potential for plantations in tropical and warmer subtropical areas of southern China. For specialty applications that produce quality solid wood end products, E. cloeziana also has promise in China. However, with much denser wood than the other species, it is less suited to production of pulp and some board products.

A key component of the Chinese-Australian cooperation projects has been the importation of genetically diverse base populations of key eucalypt species from Australia to support ongoing genetic improvement in China ${ }^{[3]}$. Through the cooperative project at Dongmen in Guangxi (1983 to 1989), more than 2650 families representing over 200 provenances of key species were established in field trials ${ }^{[16]}$. Since the early 1990 s, base populations comprising even greater numbers of families and provenances of a wider range of eucalypt species, including cold tolerant eucalypt species, have been supplied to China through various collaborative projects between CERC and the Commonwealth Scientific and Industrial Research Organisation (CSIRO), Australia, and subsequently established in field trials across southern China ${ }^{[3]}$.

Unlike most agronomic and many horticultural crops, the domestication and breeding of plantation eucalypt species is in its infancy ${ }^{[17]}$. Thus, most of the base population material of eucalypts imported into China in the 1980s and 1990s necessarily comprised unimproved seedlots representing progeny of natural stand selections. While the presence of high levels of genetic diversity for many economically important traits in such material was well known from earlier studies in numerous countries ${ }^{[17]}$, the trials at Dongmen in the 1980s and numerous 
subsequent trials elsewhere in southern China, enabled the magnitude of the phenotypic variation that manifested from this genetic diversity to be quantified ${ }^{[3,16,18]}$. Such trials also revealed better natural stand provenances, and families within these provenances, and provided a basis for selection of numerous superior trees for ongoing breeding and/or generation of hybrids through controlled-pollination. In a range-wide provenance trial of E. cloeziana at Dongmen, $\mathrm{Wei}^{[16]}$ found that the average volume production of the best provenance was 2.5 times that of the slowest-growing provenance. In an E. pellita trial established with 244 families representing 14 natural stand provenances in 1996 on the Leizhou Peninsula in Guangdong, Luo et al. ${ }^{[19]}$ found that average tree basal area for the best provenance (Mossman, Queensland) at 5year old was over $45 \%$ higher than that of the poorest provenance (Hopevale, Queensland), and differences between individual families were of a much greater magnitude, exceeding $100 \%$ for some key growth traits.

While many thousands of eucalypt families, including hundreds of hybrid families, had been included in field trials in China by 2005, the number of clones selected for commercial use up till then was limited. Investigations conducted by commercial nurseries and growers in 2005 revealed that just three clones-all E. urophylla $\times$ E. grandis selections from the early 1990 s - accounted for over $60 \%$ of plantation establishment stock being used across southern China ${ }^{[20]}$. Soon after this, the China Eucalypt Breeding Alliance (CEBA, now known as the China Eucalypt Industrial Technology Innovation Strategic Alliance), led by CERC, was formed to establish cooperation between key research institutes and major growers in order to implement well planned and coordinated improvement programs that would increase the magnitude and speed of genetic gains in key commercial eucalypt species to benefit commercial growers $^{[21]}$. The key species for this cooperative breeding program are E. camaldulensis, E. grandis, E. pellita, E. tereticornis and E. urophylla - all species well adapted to the tropical and warmer subtropical environments that are the target plantation environments for CEBA grower members.

Key priorities of CEBA have included ongoing development of advanced generation breeding populations of key eucalypt species to support ongoing, recurrent breeding and selection, and to use these to provide new superior parents for development of new superior hybrid and pure species clones. To date, members of the Alliance have established over 900 families of five key species in advanced generation breeding populations, more than 200 new hybrid families in field trials, and over 60 multisite clone trials testing over 150 clones. From this work, new superior commercial clones are now being prepared for pilot scale plantation trials.

Outside of the CEBA, separate breeding work is still being conducted by CERC, Dongmen Forest Farm,
Guangxi Forest Research Institute, Research Institute of Tropical Forestry and other institutions ${ }^{[22-24]}$. An instructive example of such work is a project hosted by CERC that, with support of the Eleventh Five-Year Science and Technology Support Project, developed 53 new hybrid combinations and selected over 50 candidate clones ${ }^{[25]}$.

To maintain and manage such eucalypt germplasm and all its inherent genetic diversity, thereby laying a firm foundation for long-term genetic improvement, China's State Forestry Administration provided funding in 2010 for development of multi-species, multisite eucalypt germplasm banks. In total, over 3000 families representing 14 important species have so far been included in the project's field trials; trials which have been designed to provide dynamic, ex-situ conservation of genetic diversity ${ }^{[26]}$.

However, the key eucalypt species adapted to tropical and warmer subtropical plantation environments in southern China, and those are the focus of CEBA's work, are not adapted to cooler, inland areas of south-central China; in these environments such eucalypts can be killed or severely damaged by low temperatures ${ }^{[27]}$. Inland Fujian, northern Guangxi, Guizhou, southern Hunan, southern Jiangxi, Sichuan, Yunnan and coastal and southern Zhejiang, are regions where eucalypt plantation development can be successful, but if and only if the correct cold tolerant eucalypt genotypes are grown. Species proven to be successful in such places include E. benthamii, E. dunnii, E. globulus, E. maidenii, E. saligna and E. smithii ${ }^{[2]}$. Progress in the domestication and genetic improvement of these species for cooler regions was greatly accelerated during the late 1990 s and early 2000 s by a Chinese-Australian collaborative $R \& D$ project on the introduction, domestication and silviculture of cold tolerant eucalypts coordinated by CERC and CSIRO ${ }^{[2]}$. Although the project has finished, improvement of cold tolerant eucalypts has continued rapidly; breeding populations for cold tolerant E. grandis and E. saligna have been established in Fujian ${ }^{[28,29]}$, for E. dunnii in Hunan ${ }^{[30]}$ and Yunnan, and other species in various regions ${ }^{[2,31,32]}$.

Genetic gains achieved in volume yields with the first and second generations of breeding of cold tolerant eucalypts are typified by those reported from $E$. dunnii in Yunnan by Shi et al. ${ }^{[33]}$. There, the best seed orchard (improved) seedlots proved to have modest gains in stem volume to 5.5 -year old, ranging from $11 \%$ to $13 \%$ over unimproved (natural stand) seedlots while a cohort of the top 10 selected families provided over $25 \%$ greater volume (Fig. 3).

\subsection{Targeted silviculture}

During the period covered by the Eighth and Ninth Fiveyear Plans, major national research projects, including "Breeding New Varieties for Eucalypt Pulp", "Optimized Cultivation Model of Eucalypt Pulp" and "Study on Breeding and Cultivation Techniques of Eucalypt Pulp", 


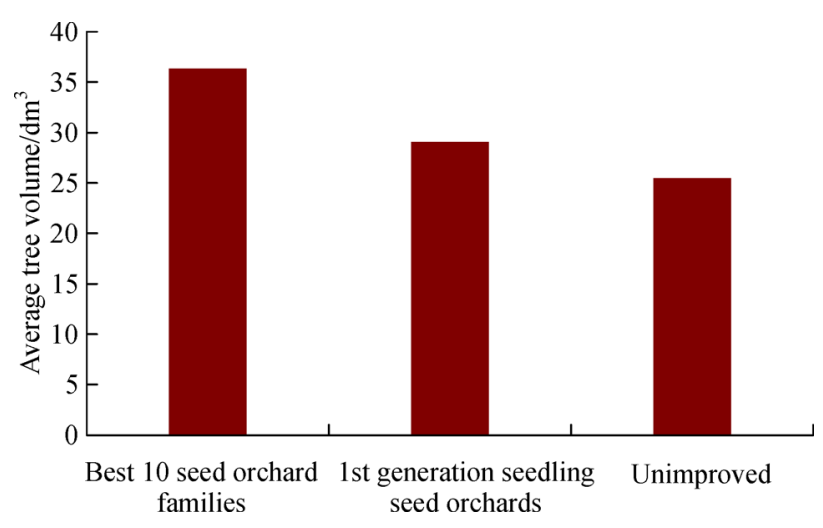

Fig. 3 Gains achieved in average tree volume of E. dunnii at age 5.5-year, with various seedlots ${ }^{[33]}$

were successfully conducted under the leadership of the CERC. Together such projects achieved results that have been adopted extensively by commercial eucalypt growers and greatly advanced the process of eucalypt plantation forestry-pulp-paper integration in China ${ }^{[34]}$.

The CERC has pioneered research in technology necessary to support cultivation of larger diameter eucalypt logs; such logs provide substantial economic benefits as they favor production of both sawn timber and high quality veneer, thereby diversifying end use options. After nearly ten years of work in this area, CERC's research has led to development of integrated technology for large-diameter eucalypt cultivation, which includes selection of improved genotypes, plantation density/spacing control, and innovations in fertilization and pruning to optimize production of clear wood in the outer bole wood ${ }^{[34-37]}$. Results from this work are already being applied in commercial plantations in at least Guangdong, Fujian and Guangxi regions.

Over the last two decades, processing young, small diameter eucalypt logs into rotary peeled veneer has developed into a huge industry across southern China. In support of this major trend, detailed research has been conducted on the yield and grade of such veneers from young ( $\leqslant 12$-year old), small diameter eucalypt logs from a wide range of clones. Just as average volume yield varies markedly among clones, veneer recovery ratios, veneer quality grades and $\log$ value was also found to vary significantly among both clones and log positions up the tree. Clones with the best veneer recovery ratios $(>50 \%$ of green volume) provided nearly twice that of the poorest clone (28.4\% of green volume) (Fig. 4). The key factor influencing veneer recovery ratios and values in small diameter eucalypt logs from young trees was found to be sweep (deviation of the log from straightness), with defects relating to branches and knots proving key determinants of veneer quality grades ${ }^{[35,38,39]}$. Research has also found that considerable improvements in veneer sheet quality can be achieved by timely green pruning (i.e., removal of lateral branches before branch death) of young eucalypt trees ${ }^{[37]}$.

\subsection{Eucalypt disease and pest management}

Important diseases of plantation eucalypts in China are mainly bacterial wilt caused by Ralstonia solanacearum $^{[40]}$; stem diseases caused by Teratosphaeria zuluensis $^{[41,42]}$ and species of Botryosphaeriaceae ${ }^{[43]}$,

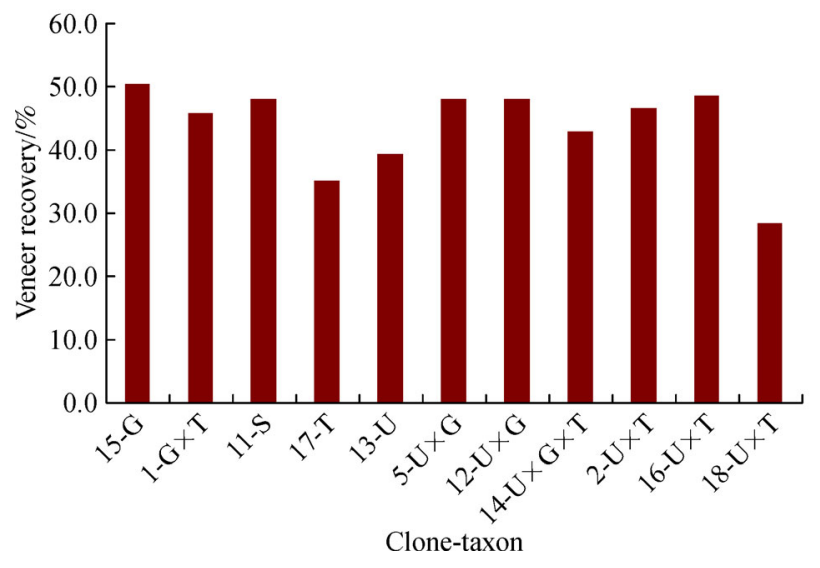

Fig. 4 Recovery of veneer by clone (and taxon) from 5-year old eucalypt trees. Key to taxa: G, E. grandis; S, E. saligna; T, E. tereticornis; U, E. urophylla ${ }^{[35]}$. 
Cryphonectriaceae $^{[44,45]}$ and Ceratocystis ${ }^{[46,47]}$; and also leaf diseases caused by species of Calonectria ${ }^{[48-51]}$, Quambalaria $^{[52]}$, Mycosphaerellaceae and Teratosphaeriacea $^{[53,54]}$. The key insect pests afflicting Eucalyptus plantations in China include leaf eating pests, such as Biston suppressaria (syn. Buzura suppressaria); drill stem pests like Leptocybe invasa and Endoclyta signifier; and underground pests such as Odontotermes formosanus ${ }^{[55]}$.

Significant pest and disease issues of plantation eucalypts in China have been increasing in frequency and severity over time ${ }^{[56,57]}$. Research has shown that the species diversity and population diversity within species of some pathogens causing major diseases in China are $\operatorname{high}^{[42,48,50]}$. There is also evidence that the current diversity in some pathogens reflects changes resulting from long-term interactions with Eucalyptus species in the plantations in China, and some pathogens may even have originated in China.

Chinese researchers have monitored the occurrence and development of diseases and pests of Eucalyptus species and effectively protected plantation resources by integrated approaches involving physical, chemical and biological countermeasures as well as breeding of resistant eucalypt genotypes. For example, the use of pesticides has effectively controlled the spread of pests ${ }^{[58-60]}$. Resistance of different Eucalyptus clones to stem canker caused by species of Botryosphaeriaceae and Cryphonectriaceae and leaf disease caused by Calonectria species, has been tested $^{[43-49,61]}$. Also, resistance of different Eucalyptus species, seed sources, families and individual genotypes to the insect pest Leptocybe invasa has been quantified ${ }^{[62,63]}$. Significant differences in disease and insect resistance have been found among genetic materials ${ }^{[39-49,61,63]}$. Selection of resistant genotypes is a key element of research, and integrated prevention and control of diseases and pests on eucalypts in China.

\subsection{Enhancing plantation ecology and sustainability}

Long-term monitoring of Eucalyptus plantation ecosystems in China commenced relatively recently. In 2012, Guangdong Zhanjiang Eucalypt Plantation Ecosystem Research Station, a national facility, was officially opened to conduct long-term monitoring and research. This facility has already provided valuable data on plantation ecosystems and their interactions with local and regional ecosystems. Key results obtained to date are detailed below.

\subsubsection{Ecological hydrology}

Water use studies on seedlings and plantation Eucalyptus trees of varying ages revealed that plantation water use is generally within the range from 0.5 to $6.0 \mathrm{~mm} \cdot \mathrm{d}^{-1}$, and mostly within the range of 2 to $4 \mathrm{~mm} \cdot \mathrm{d}^{-1[64-67]}$. Other hydrological processes, including interception, infiltration, soil moisture, surface runoff, groundwater levels and soil water holding capacity, have also been studied in eucalypt plantations $^{[68-75]}$.

Eucalypt plantations often lead to greater controversy in regards to land use and environmental issues compared with forests planted with other species. While under continuous cropping and short rotations, the hydrological functions of eucalypt plantation ecosystems may be decreased, detailed field studies have shown that water use by Eucalyptus plantations in Guangxi (and areas in Guangdong with similar rainfalls) is generally less than $70 \%$ of rainfall and that such plantations do not have important effects on annual stream flow in large primary catchments ${ }^{[76]}$. Even so, most research on plantation water use in China has been scattered and not systematic. Therefore, future research should be better coordinated with close collaboration between different disciplines and institutions to ensure research outcomes are wider ranging, more scientifically robust and more widely applicable.

\subsubsection{Nutrient cycling}

Detailed research has been undertaken on nutrient dynamics of eucalypt plantations of different ages ${ }^{[77-79]}$ and nutrient concentrations in different components of plantation biomass ${ }^{[80]}$. The dynamic balance of nutrients in individual trees within plantations has also been determined, along with studies on the impacts of supplemental nutrient applications on such nutrient balances ${ }^{[81,82]}$. Also, recognizing common industry practices of cultivating fast growing, short rotation eucalypt plantations over multiple rotations, changes of soil chemical, biological and physical properties over time (including soil physical and chemical properties, microorganisms and soil enzymes) have been investigated $^{[83-86]}$. This work has shown that nutrient content of soil under eucalypt plantations decreases to various degrees with successive rotations. It has also been shown that sound, scientifically based plantation management, including setting and balancing fertilization formulations based on soil testing, in conjunction with mixed and conservative harvesting methods can enhance eucalypt plantation growth and recovery of soil fertility. However, the reproducibility of such benefits will vary with site conditions, and the presence and intensity of competing vegetation.

\subsubsection{Carbon sequestration by eucalypt plantations}

Carbon contents of ecosystem biomass along with carbon allocation patterns of eucalypt trees of different ages and on different sites has been investigated ${ }^{[87-89]}$. The average annual carbon sequestration of China's eucalypt plantations is estimated to be around $10 \mathrm{t}$ per year, revealing that 
they have good potential for substantial carbon sequestration $^{[90]}$. Research on the soil carbon contents and carbon fluxes of eucalypt plantations in China have shown that high intensity plantation management (particularly with physical soil disturbance) can significantly reduce soil carbon content, that applications of $\mathrm{N}$ fertilizers can increase soil $\mathrm{CO}_{2}$ emissions ${ }^{[91]}$ and that eucalypt plantation undergrowth can reduce soil respiration rates ${ }^{[22]}$.

\subsubsection{Eucalypt plantation biodiversity}

As exotic species, plantation eucalypts can also create controversy with respect to their impacts on the biodiversity of local ecosystems. Compared with the native forests, the biodiversity of native plants, animals and soil in eucalypt plantation is somewhat decreased, but the fact that eucalypt plantations often have significantly higher biodiversity than most alternative economic uses of the same lands is often overlooked ${ }^{[93]}$. By reducing site disturbance associated with plantation establishment and management operations, and with increasing plantation age, the biodiversity in eucalypt plantations generally increased ${ }^{[94-96]}$. Research has also shown that some of the main factors affecting biodiversity in eucalypt plantations are crown height, leaf area index of the tree canopy and soil nutrient status ${ }^{[97]}$.

\subsection{Wood processing and byproduct technology}

A number of significant advances have been achieved in eucalypt pulping technology in China over the last decade. One is the successful development of a double-screw extruder for use in pre-impregnation of Eucalyptus wood chips. A second is the development of equipment for use with such double-screw extruders that enables chips to be mixed with pulping liquids and bleach as they are extruded, reducing total energy consumption by $10 \%$ to $30 \%$ and resulting in and improved pulp qualities ${ }^{[98-105]}$.

For production of quality eucalypt plywood in China, numerous technical challenges associated with production of veneers from young, small diameter eucalypt logs have had to be overcome in the past 20 years or so. Improved veneering technology has enabled residual core diameters with rotary peeling of eucalypt veneer to be reduced from the previously common $150 \mathrm{~mm}$ to less than $30 \mathrm{~mm}^{[106,107]}$. This has markedly increased veneer production efficiencies, particularly for small diameter logs.

Existing veneer drying equipment and technology have also been transformed to optimize performance with eucalypt veneers ${ }^{[108,109]}$ and thermal recovery systems have been developed to improve energy efficien$\operatorname{cies}^{[110,111]}$. For manufacture of 'laminated veneer lumbers' (LVL) using 4.5 and $6.0 \mathrm{~mm}$ thick eucalypt veneers as raw material, adhesive application at rates of $200 \mathrm{~g} \cdot \mathrm{m}^{-2}$ of eucalypt veneer have proved able to provide strength indices sufficiently high for the LVL to meet the national standard requirements ${ }^{[112]}$. When composite flame retardant treatments are applied to eucalypt and poplar veneers and then plywood is manufactured from these veneers, subsequent tests have shown that by most physical, mechanical and flame retardant measures, the plywood made from eucalypt veneers is generally superior to that from the poplar veneers ${ }^{[113]}$.

There is substantial potential for commercial development of valuable natural plant extract products from Eucalyptus species in China, especially as byproducts of commercial timber producing plantations. Recent research in this area has included studies on increasing extraction of eucalypt essential leaf oils ${ }^{[114,115]}$, screening of eucalypt species and genotypes for valuable polyphenols ${ }^{[116]}$ and evaluating contents of key antioxidant polyphenols from E. urophylla $\times E$. grandis and optimizing their efficacy as anti-aging medications ${ }^{[117-119]}$. This latter research also solved some key technical problems of the extraction and purification of such phenolic compounds from eucalypt species, by using continuous phase transformation, laying a foundation for commencing of pilot scale production.

\section{Conclusions}

Chinese investments in eucalypt R\&D have resulted in development of a large number of improved eucalypt genotypes and improved silvicultural technology. Together, these have enabled eucalypt plantation growth rates (mean annual increment, MAI) to increase from an average of $5-8 \mathrm{~m}^{3} \cdot \mathrm{hm}^{-2}$ per year in the $1980 \mathrm{~s}$ to $25-40 \mathrm{~m}^{3} \cdot \mathrm{hm}^{-2}$ per year in the $2010 \mathrm{~s}$, delivering substantial economic benefits to growers.

In summary, the development of China's eucalypt industry has made important contributions to both the national economy and the livelihoods of a substantial number of Chinese people. These contributions include four key areas: (1) a contribution of around 25\% to domestic wood production, which protects national wood and fiber security; (2) a complete industry with an annual turnover valued at over 300 billion CNY, which substantially contributes to local economic development in many parts of southern China; (3) a substantial carbon sink; and (4) livelihoods and financial security for tens of thousands of rural households.

Acknowledgements We gratefully acknowledge financial support for eucalypt research through the National Natural Science Foundation of China (31570615), the Chinese Ministry of Science and Technology the Thirteenth Key Research and Development Project (2016YFD0600500), and the Special Public Welfare Forestry Research Fund of the State Forestry Administration of China (201104003). We thank our colleagues, Chao Li and Jiaqi Zheng for their valuable assistance.

Compliance with ethics guidelines Yaojian Xie, Roger J. Arnold, Zhihua 
Wu, Shuaifei Chen, Apeng Du, and Jianzhong Luo declare that they have no conflicts of interest or financial conflicts to disclose.

This article is a review and does not contain any studies with human or animal subjects performed by any of the authors.

\section{References}

1. Qi S X. Eucalyptus in China. Beijing: China Forestry Publishing House, 2002 (in Chinese)

2. Arnold R J, Luo J Z, Clarke B. Trials of cold tolerant eucalypt species in cooler regions of South Central China. Canberra: Australian Centre for International Agricultural Research, 2004

3. Turnbull J W. Development of sustainable forestry plantations in China: a review. Canberra: Australian Centre for International Agricultural Research, 2007

4. Xie Y J. The Reality of Eucalyptus. Beijing: China Forestry Publishing House, 2015 (in Chinese)

5. Arnold R J, Xie Y J, Midgley S J, Luo J Z, Chen X F. Emergence and rise of eucalypt veneer production in China. International Forestry Review, 2013, 15(1): 33-47

6. Chinese Society of Forestry. Investigation report on scientific development of Eucalyptus. Beijing: China Forestry Publishing House, 2016 (in Chinese)

7. Sha Y E, Wu Z H, Ouyang L J, Huang Z C, Zeng F H, Li Z F. Tissue culture and regeneration of Eucalyptus pellita. Journal of Southern Agriculture, 2013, 44(9): 1511-1516 (in Chinese)

8. Han C, Xu X L. Research of anatomy observation on adventitious rooting genesis and development of three rooting culture seedlings of Eucalyptus. Acta Botanica Boreali-Occidentalia Sinica, 2016, 36(8): 1594-1599 (in Chinese)

9. Sun $\mathrm{C}$ B, Guo D, Zhang L Y. Callus induction and in vitro regeneration for Eucalyptus urophylla $\times$ E. grandis. Genomics and Applied Biology, 2012, 31(6): 592-596 (in Chinese)

10. Xie Y J, Zhang S C, Tan X F. Light medium formulation for Eucalyptus cutting culture. Journal of Central South University of Forestry \& Technology, 2008, 28(4): 62-66 (in Chinese)

11. Shang X H, Xie Y J, Yang X H, Zhang P J, Peng Y. Different mixing proportion media on Eucalyptus seedling. Chinese Journal of Tropical Crops, 2012, 33(12): 2150-2155 (in Chinese)

12. Zhang P J, Xie Y J, Peng Y, Shang X H. Effect of the variance of Eucalyptus-bark media physicochemical properties on growth of Eucalyptus seedling. Guangdong Agricultural Science, 2011, 10: 59-61 (in Chinese)

13. Wu Q, Wei S Q, Qin W N, Xian P, Jiang H B. Influences of biogas slurry irrigation on the growth of Eucalyptus seedlings. China Forestry Science and Technology, 2015, 29(1): 23-26 (in Chinese)

14. Tan C Q, Qin S J, Qin M, Wang L H, Fang L, Fang X. Effect of special fertilizer for E. urophylla $\times$ E. grandis DH32-29 seedling growth. Journal of Northwest Forestry University, 2014, 29(2): 125-128 (in Chinese)

15. Zhang H L, Peng Y, Xie Y J, Luo P. Effects of two nitrogen application methods on growth of Eucalyptus urophylla $\times$ E. grandis container seedlings cultivated with light media. Journal of Nanjing Forestry University: Natural Science Edition, 2014, 38 (1): 53-58 (in Chinese)
16. Wei J. Research achievements of the Dongmen Eucalyptus demonstration project. In: Proceedings of Regional Expert Consultation on Eucalyptus 1993, Bangkok. Bangkok: FAO Regional Office for Asia and the Pacific, 1996, 33-45

17. Eldridge K G, Davidson J, Harwood C E, van Wyk G. Eucalypt domestication and breeding. Oxford: Oxford University Press, 1993

18. Luo J, Zhou G, Wu B, Chen D, Cao J, Lu W, Pegg R E, Arnold R J. Genetic variation and age-age correlations of Eucalyptus grandis at Dongmen forest farm in southern China. Australian Forestry, 2010, 73(2): 67-80

19. Luo J, Arnold R, Aken K. Genetic variation in growth and typhoon resistance in Eucalyptus pellita in south-western China. Australian Forestry, 2006, 69(1): 38-47

20. Wei R P. Genetic diversity and sustainable productivity of eucalypt plantations in China. In: Wang H R, eds. Changing Patterns: Tree Introduction and Phytogeography. Beijing: China Forestry Publishing House, 2005, 19-27 (in Chinese)

21. Arnold R J, Luo J Z, Lu W H, Wang C B, Lin Y. Co-operative improvement of key eucalypt species in China. In: Scientific Cultivation and Green Development to Enhance the Sustainability of Eucalypt Plantations. IUFRO Eucalypt Conference 2015, Guangdong, 53

22. Li C R, Wu B, Chen D L. Comprehensive evaluation of multiple characters of E. grandis hybrid clones. Forestry Sciences, 2014, 43 (4): $37-43$

23. Wu S, Zhu Y, Xu J, Lu Z, Chen G, Song P, Guo W. Genetic variation and genetic gain for energy production, growth traits and wood properties in Eucalyptus hybrid clones in China. Australian Forestry, 2017: 1-9

24. Zhang L, Mo J Y, Lan J, Li H L, Wang J Z. Selective breeding and cultivation of Eucalyptus variety DH191-4. Eucalypt Science and Technology, 2016, 33(4): 32-34 (in Chinese)

25. Luo J Z, Arnold R J, Cao J G, Lu W H, Ren S Q, Xie Y J. Variation in pulp wood traits between eucalypt clones across sites and implications for deployment strategies. Journal of Tropical Forest Science, 2012, 24(1): 70-82

26. Luo J Z, Arnold R J, Lu W H, Lin Y, Wang C B, Xie Y J. Development of Eucalypt Germplasm Banks in China. In: Scientific cultivation and green development to enhance the sustainability of eucalypt plantations - abstracts. IUFRO Eucalypt Conference 2015, Guangdong. 65

27. Arnold R J, Luo J Z. Cold tolerant plantation eucalypts for south central China. In: Wei R P, Xu D P, eds. World Scientific. Singapore: Eucalypt Plantations - Research, Management and Development, 2003, 90-101

28. Qiu J Q, Lan H S, Xie G Y, Huang D L. A preliminary report on the provenance/family trial on Eucalyptus grandis. Acta Agriculturae Unversitatis Jiangxiensis, 2002, 24: 517-521 (in Chinese)

29. Lan H, Huang X, Luo J, Arnold R J. Genetic variation in growth and stem straightness in Eucalyptus saligna trials in Fujian. Australian Forestry, 2012, 75(3): 163-174

30. Li B, Arnold R J, Luo J, Li Z. Genetic variation in growth, cold tolerance and coppicing in Eucalyptus dunnii trials in Hunan, China. Australian Forestry, 2012, 75(4): 215-224

31. Arnold R J, Li B, Luo J, Bai F, Baker T. Selection of cold tolerant 
Eucalyptus species and provenances for inland frost susceptible, humid sub-tropical regions of southern China. Australian Forestry, 2015, 78(3): 180-193

32. Li B H, Arnold R J, Luo J Z, Baker T G. Evaluation of Eucalyptus red gum species and provenances for inland humid subtropical regions of southern China. Australian Forestry, 2016, 79(1): 43-52

33. Shi T Y, Arnold R J, Kang W L, Duan F W, Qian Y X, Xie H, Xu J M. Genetic variation and gains for two generations of Eucalyptus dunnii in China. Australian Forestry, 2016, 79(1): 15-24

34. Liu Q, Chen S X, Li Z H, Arnold R J. Growth response and wound occlusion in pruned Corymbia torelliana. Journal of Tropical Forest Science, 2012, 24(2): 187-197

35. Luo J Z, Arnold R J, Ren S Q, Jiang Y D, Lu W, Peng Y, Xie Y J. Veneer grades, recoveries and values from 5-year old eucalypt clones. Annals of Forest Science, 2013, 70(4): 417-428

36. Li G Y, Xu J M, Peng S Y. WuS J, ChenW P, Jian M, Ou S, Han C, $\mathrm{Hu} \mathrm{X}$ X. Study on early growth performance and optimum cultivation patterns of Eucalyptus clonal plantations for plywood. Eucalypt Science \& Technology, 2014, 31(3): 22-27 (in Chinese)

37. Peng Y, Washusen R, Xiang D, Lan J, Chen S, Arnold R J. Grade and value variations in Eucalyptus urophylla $\times$ grandis veneer due to variations in initial plantation spacings. Australian Forestry, 2014, 77(1): 39-50

38. Ren S Q, Luo J Z, Xie Y J, Peng Y, Chen J B, Lu W H, Jiang Y. Study on factors influencing veneer recovery ratio and value of eucalypt wood. Eucalypt Science \& Technology, 2010, 27(2): 1-7 (in Chinese)

39. Ren S Q, Luo J Z, Peng Y, Xie Y J, Lu W H, Cao J G, Jiang Y. A study on veneer recovery ratio and value of eucalypt clones. Acta Prataculturae Sinica, 2010, 19(6): 46-54 (in Chinese)

40. Wang Y, Arnold R J, Li G Q, Xie Y J, Zhou X D. Identification and rapid detection of bacterial wilt in plantation Eucalyptus in China. Australian Forestry, 2014, 77(2): 133-139

41. Cortinas M N, Burgess T, Dell B, Xu D, Crous P W, Wingfield B D, Wingfield M J. First record of Colletogloeopsis zuluense comb. nov., causing a stem canker of Eucalyptus in China. Mycological Research, 2006, 110(Pt 2): 229-236

42. Chen S F, Barnes I, Chungu D, Roux J, Wingfield M J, Xie Y J, Zhou X D. High population diversity and increasing importance of the Eucalyptus stem canker pathogen, Teratosphaeria zuluensis, in South China. Australasian Plant Pathology, 2011, 40(4): 407-415

43. Chen S F, Pavlic D, Roux J, Slippers B, Xie Y J, Wingfield M J, Zhou X D. Characterization of Botryosphaeriaceae from plantation-grown Eucalyptus species in South China. Plant Pathology, 2011, 60(4): 739-751

44. Chen S F, Gryzenhout M, Roux J, Xie Y J, Wingfield M J, Zhou X D. Identification and pathogenicity of Chrysoporthe cubensis on Eucalyptus and Syzygium spp. in South China. Plant Disease, 2010, 94(9): 1143-1150

45. Chen S, Gryzenhout M, Roux J, Xie Y, Wingfield M J, Zhou X. Novel species of Celoporthe from Eucalyptus and Syzygium trees in China and Indonesia. Mycologia, 2011, 103(6): 1384-1410

46. Chen S F, Van Wyk M, Roux J, Wingfield M J, Xie Y J, Zhou X D. Taxonomy and pathogenicity of Ceratocystis species on Eucalyptus trees in South China, including C. chinaeucensis sp. nov. Fungal Diversity, 2013, 58(1): 267-279
47. Liu F, Mbenoun M, Barnes I, Roux J, Wingfield M J, Li G, Li J, Chen S. New Ceratocystis species from Eucalyptus and Cunninghamia in South China. Antonie van Leeuwenhoek, 2015, 107(6): 1451-1473

48. Chen S F, Lombard L, Roux J, Xie Y J, Wingfield M J, Zhou X D. Novel species of Calonectria associated with Eucalyptus leaf blight in Southeast China. Persoonia, 2011, 26(1): 1-12

49. Lombard L, Zhou X D, Crous P W, Wingfield B D, Wingfield M J. Calonectria species associated with cutting rot of Eucalyptus. Persoonia, 2010, 24(1): 1-11

50. Lombard L, Chen S F, Mou X, Zhou X D, Crous P W, Wingfield M J. New species, hyper-diversity and potential importance of Calonectria spp. from Eucalyptus in South China. Studies in Mycology, 2015, 80: 151-188

51. Zhu J H, Guo W S, Chen H M, Wu J Q, Chen Q Z, Meng X M. Loss estimation of Eucalyptus growth caused by Eucalyptus dieback. Forest Pest and Disease, 2011, (5): 6-10 (in Chinese)

52. Zhou X D, De Beer Z W, Xie Y J, Pegg G S, Wingfield M J. DNAbased identification of Quambalaria pitereka causing severe leaf blight of Corymbia citriodora in China. Fungal Diversity, 2007, 25: $245-254$

53. Burgess T I, Andjic V, Hardy G S, Dell B, Xu D. First report of Phaeophleospora destructans in China. Journal of Tropical Forest Science, 2006, 18: 144-146

54. Burgess T I, Barber P A, Sufaati S, Xu D, Hardy G S, Dell B. Mycosphaerella spp. on Eucalyptus in Asia: new species, new hosts and new records. Fungal Diversity, 2007, 24: 135-157

55. Luo J T, Wu Y J, Xi F S. 2012. Control technologies and original ecological figures for major diseases and pests of fast-growing Eucalyptus plantations. Guangxi: Guangxi Science and Technology Press, 2012 (in Chinese)

56. Zhou X D, Wingfield M J. Eucalypt diseases and their management in China. Australasian Plant Pathology, 2011, 40(4): 339-345

57. Pang Z H. Current situation and development in trend of Eucalyptus pest in China. Journal of Guangxi Academy of Sciences, 2013, 29(3): 192-206 (in Chinese)

58. Jiang X J, Chen C Z, Wu Y J. Study on control technology of termites in young Eucalyptus plantation. Guangxi Forestry Science, 2010, 39(1): 1-4 (in Chinese)

59. Cao S G, Luo S N, He R H. Experimental study of different insecticide on Endoclyta signify Walker Larva. Modern Agricultural Sciences and Technology, 2012, 10: 157-163 (in Chinese)

60. Huang S X. Experiment on different pesticides controlling of Buzura suppressaria (Guenée) in eucalypt plantation. Forestry Prospect and Design, 2014, 1: 107-110 (in Chinese)

61. Li G Q, Li J Q, Liu F F, Li T H, Chen S F. Preliminary analyses on pathogenicity of twelve Calonectria spp. on ten Eucalyptus clones in China. Eucalypt Science \& Technology, 2014, 31: 1-7 (in Chinese)

62. Huang Y H, Zhang N D, He P L, Huang S B, Huang H H, Chen R P. Resistance of different Eucalyptus strains to Leptocybe invasa Fisher \& La Salle. Chinese Journal of Biological Control, 2014, 30 (3): 316-322 (in Chinese)

63. Luo J Z, Arnold R J, Lu W H, Lin Y. Genetic variation in Eucalyptus camaldulensis and E. tereticornis for early growth and susceptibility to the gall wasp Leptocybe invasa in China. 
Euphytica, 2014, 196(3): 397-411

64. Liu G C, Du A P, Zao Z Y, Xie Y J, Zhang J. Transpiration and water consumption of Eucalyptus urophylla plantations on the Leizhou Peninsula. Journal of Huangzhong Agricultural University, 2015, 34(6): 27-32 (in Chinese)

65. Hua L, He Q, Li J Y, Liu S, Yu F. Comparison of the water consumption characteristics of Eucalyptus and Corymbia clone seedlings and the local indigenous tree species Bischofia javanica. Chinese Journal of Applied Ecology, 2014, 25(6): 1639-1644 (in Chinese)

66. Wu J Y, Zao C J, Xu W X, Zuo Z Q, Zhou M J. Characteristics of the sap flow rate of the young Eucalyptus and its response to environmental factors. Journal of Northwest Forestry University, 2015, 30(5): 46-52 (in Chinese)

67. Wang Z C, Du A P. Characteristics of stem sap flow of eucalypt and its relation to environmental factors. Journal of Northeast Forestry University, 2016, 44(5): 24-28 (in Chinese)

68. Shi Z J, Xu D P, Zhang N N, Qiu Z J, Hu Z S, Guo J Y. Progress in researches on hydrological effects of Eucalyptus plantation. Scientia Silvae Sinicae, 2009, 45(11): 135-140 (in Chinese)

69. Shi Z J, Zhang N N, He C Q, Qiu Z J, Xu D P, Gao J X, Hu Z S. Eco-hydrological effect of the canopy, litter and soil of a eucalyptus plantation in South China. Acta Ecologica Sinica, 2010, 30(7): 1932-1939 (in Chinese)

70. Zhang N N. Studies on water use of eucalyptus plantations in Guangdong. Dissertation for the Doctoral Degree. Beijing: Chinese Academy of Forestry Sciences, 2010 (in Chinese)

71. Zhao C J, Wu J Y, Kang M Y, Fan W B, Lin Z, Zhuo Z Q. Variation of soil moisture content for Eucalyptus forests and its response to stand ages in Western Hainan. Acta Ecologica Sinica, 2015, 35(6): 1734-1742 (in Chinese)

72. Zhong H T. Impact on soil and water loss and soil moisture of Eucalyptus forest land for different afforestation tending measures. Dissertation for the Master Degree. Guangxi: Guangxi University, 2016 (in Chinese)

73. Yang G R. Impact on Eucalyptus plantation on water yield and water quality in the forest catchments. Dissertation for the Doctoral Degree. Guangxi: Guangxi University, 2012 (in Chinese)

74. Wang J J, Yu Y C, Chen R, Wang W, Liang G F, Zhou C F, Yu X P. Soil infiltration characteristics of Eucalyptus plantation with different rotations and ages. Journal of Soil and Water Conservation, 2011, 25(2): 78-82 (in Chinese)

75. Hang Y S, Wei Y C, Ouyang Z Y, Cao Y. Effects of continuous planting rotation on forest structural characteristics and water holding capacity of Eucalyptus plantations. Acta Ecologica Sinica, 2008, 28(9): 4609-4617 (in Chinese)

76. Liao G R, Zhong J H, Li S Y, Lan P L, Liao Y R, Wang S M, Yang $\mathrm{G}$ Q, Jian M, Li H. The nutrient cycling and balance of Eucalyptus plantation ecosystem II. The nutrient cycling of Eucalyptus plantation ecosystem. Ecology \& Environment, 2003, 12(3): 300-302 (in Chinese)

77. Liao G R, Li S Y, Lan P L, Liao Y R, Wang S M, Yang G Q, Jian M, Li H. The nutrient cycling and balance of Eucalyptus plantation ecosystem I. The nutrient storage of Eucalyptus plantation ecosystem. Ecology \& Environment, 2003, 12(2): 150-154 (in Chinese)
78. Liu W F, Fan H B, Gao C F, Huang R Z, Su B Q. Litter production and its nutrient fluxes in an age sequence of Eucalyptus plantations. Chinese Journal of Ecology, 2009, 28(10): 1928-1934 (in Chinese)

79. Fan H B, Yuan Y H, Liao Y C, Li Y Y, Su B Q, Gao C F. Soil nutrient dynamics in sequentially aged Eucalyptus plantations in mountainous region of southern Fujian, China. Chinese Journal of Applied and Environmental Biology, 2009, 15(6): 756-760 (in Chinese)

80. Lin G Z. Effect of water and fertilizer on growth and physiological characteristics of Eucalyptus seedlings. Dissertation for the Master Degree. Beijing: Chinese Academy of Forestry Sciences, 2012 (in Chinese)

81. Wang $\mathrm{C} X$. The growth and the root morphology of young Eucalyptus urophylla $\times$ E. grandis forest to different kinds of fertilizers. Dissertation for the Master Degree. Hunan: Central South University of Forestry and Technology, 2014 (in Chinese)

82. Zhang K, Zheng H, Chen F L, Ouyang Z Y, Lan J, Wu Y F, Xiang X W. Impacts on replacement of Pinus with Eucalyptus on soil nutrients and enzyme activities. Acta Pedologica Sinica, 2015, 52 (3): 646-653 (in Chinese)

83. Liu L L, Yang C L, Jiang D H, Xiao B, Cui J F. Soil nutrients and enzymes activity in Eucalyptus plantations under different rotations of continuously planting. Chinese Journal of Tropical Crops, 2013, 34(11): 2117-2120 (in Chinese)

84. Liu H Y. The relationship of soil enzyme activities between soil nutrients in a long-term continuous planting Eucalyptus plantation. Dissertation for the Master Degree. Guangxi: Guangxi University, 2013 (in Chinese)

85. Wen Y G, Zheng X, Li M C, Xu H G, Liang H W, Huang C B, Zhu $\mathrm{H} \mathrm{G}, \mathrm{He}$ B. Effects of eucalypt plantation replacing Masson pine forest on soil physiochemical properties in Guangxi, southern China. Journal of Beijing Forestry University, 2009, 31(6): 145148 (in Chinese)

86. Wen L, Wang K L, Zeng Y P, Peng W X, Du H, Li S S, Song T Q. Carbon storage and its distribution in Eucalyptus urophylla $\times$ E. grandis plantations at different stand ages. Acta Botanica Boreali-Occidentalia Sinica, 2014, 34(8): 1676-1684 (in Chinese)

87. Wang C B, Liu L T, Mo X Y. Carbon storage analysis of 30 Eucalyptus clonal plantation. Forest Research, 2013, 26(5): 661667 (in Chinese)

88. Li Q, Xiao J H, Feng Y, Xiao W F. Carbon stocks and carbon sequestration capacity of the main plantations in China. Journal of Northwest Forestry University, 2016, 31(4): 1-6 (in Chinese)

89. Yao P, Chen X G, Zhou Y F, Zao W J, Lu M, Tu J. Carbon sequestration potential of the major stands under the Grain for Green Program in Southwest China in the next 50 years. Acta Ecologica Sinica, 2014, 34(11): 3025-3037 (in Chinese)

90. Li R D, Zhang K, Su D, Lu F, Wan W Y, Wang X K, Zheng H. Effects of nitrogen application on soil greenhouse gas fluxes in a Eucalyptus plantation during the growing season. Acta Ecologica Sinica, 2015, 35(18): 5931-5939 (in Chinese)

91. Wu M. Characteristics on soil respiration of Eucalyptus spp. plantations and several other forests in Guangxi. Dissertation for the Master Degree. Guangxi: Guangxi Normal University, 2014 (in Chinese) 
92. Ping L, Xie Z Q. Effects of introducing Eucalyptus on indigenous biodiversity. Chinese Journal of Applied Ecology, 2009, 20(7): 1765-1774 (in Chinese)

93. Zao Y H, Yang Y M, Yang S Y, Du F, Li N. Effect of on cultivation measures on undergrowth vegetation species diversity of Eucalyptus plantation. Journal of Yunnan Agricultural University, 2008, 23(3): 309-314 (in Chinese)

94. Guo D D, Zhang W Q, Lo Z Q, Zhou P. Plant biodiversity on Eucalyptus plantation of different ages in Northern Guangdong. Ecologic Science, 2015, 34(3): 65-70 (in Chinese)

95. Zhang D J, Zhang J, Yang W Q, Wu F Z, Huang Y M, Zhang Z W, Wang X, Wang X Q, Zhu L. Plant's and soil organism's diversity across a range of Eucalyptus grandis plantation ages. Acta Ecologica Sinica, 2013, 33(13): 3947-3962 (in Chinese)

96. Li W, Zhang C P, Wei R P. Relationship of under-story vegetation diversity with stand age and soil factor of Eucalyptus plantations in central-western Guangdong. Acta Ecologica Sinica, 2014, 34(17): 4957-4965 (in Chinese)

97. Xiang Y Z, Xu D P, Yang Z J, Zhang N N, Guo J Y. Relationship between plant species diversities and soil hydro-physical properties in two plantations in Hainan Province. Research of Soil and Water Conservation, 2012, 19(1): 37-41 (in Chinese)

98. Deng Y J, Fang G G, Hang S M, Jiao J, Li P, Li H B, Liang F M, Liu C. Application of weighted ranking method for cleaner production audit in enterprise. Paper Science \& Technology, 2011, 30(3): 1-5 (in Chinese)

99. Gao G L, Lin B P, Shen K Z, Fang G G, Deng Y J, Liu S S, Jin L. The effect of lignin content on pulp fiber surface on the sheet strength. Transactions of China Pulp and Paper, 2012, 27(1): 9-12 (in Chinese)

100. Gao G L, Shen K Z, Fang G G, Deng Y J, Li P, Jin L, Bie S X. Research progress in cellulose-based absorbent material. Paper Science \& Technology, 2012, 31(5): 57-64 (in Chinese)

101. Liang F M, Fang G G, Deng Y J, Han S M, Jiao J, Li H B, Peng S $\mathrm{Y}, \mathrm{Xu} \mathrm{J}$ M. Pulpwood properties of improved hybrid Eucalyptus urophylla $\times$ E. tereticornis with different tree-age and analysis of APMP pulping properties. Paper Science \& Technology, 2013, 32 (5): 1-6 (in Chinese)

102. Gao G L, Shen K Z, Fang G G. Synthesis of Celluloses-AA-SPS super absorbent resin by using an interpenetrating net structure technique directly from Eucalyptus BKP. Transactions of China Pulp and Paper, 2014, 29: 464-472 (in Chinese)

103. Liang F M, Fang G G, Deng Y J, Han S M, Jiao J, Pan A X, Peng S $\mathrm{Y}, \mathrm{Xu} J \mathrm{M}$. An evaluation model for high yield pulping properties from fast-growing woods. Paper Science \& Technology, 2015, 34 (2): 7-11 (in Chinese)

104. Guo W L, Shi Y Q, Deng Y J, Ding L B, Fang G G. Determination of volumetric isothermal expansivity of waste liquor from chemimechanical pulping. China Pulp \& Paper Industry, 2014, (14):2426 (in Chinese)

105. Li S H, Shi Y Q, Cui H H, Hang S M, Fang G G. The effects of the second-stage impregnation process on the capabilities of the pulp and the wastewater using Eucalyptus. Paper Chemicals, 2014, 26 (5): 7-14 (in Chinese)

106. Sun F, Zhou Y D, He Z Q, Hu L, Zan M J. Study on veneer recovery of eucalypt $\log$ by spindle-less lathes. Wood Processing Machinery, 2012, 40(10): 11-14 (in Chinese)

107. Han C J, Mi X J, Jiang J L, Jiang J H, Lv J X. Moisture content distribution of multiple Eucalyptus veneers during hot-pressdrying. Wood Research, 2014, 59(2): 351-358 (in Chinese)

108. He Z Q, Zhou Y D, Peng L M, Sun F. Energy consumption analysis of commonly used veneer dryers. China Wood Industry, 2012, 26(1): 35-38 (in Chinese)

109. Sun F, Zhou Y D, He Z Q. Current status and development of energy conservation in china's veneer drying process. China Wood Industry, 2012, 26(6): 35-38 (in Chinese)

110. Yu Y L, Yu W J. Advance in the study of high value-added utilization of small-size Eucalyptus. China Forest Products Industry, 2013, 40(1): 5-8 (in Chinese)

111. Han C J, Lv J X, Xu J M, Jiang J L. Temperature distribution of pre-drying Eucalyptus veneers during hot press drying. Journal of Northeast Forestry University, 2014, 42(6): 86-89 (in Chinese)

112. Meng F D, Wu B L, Yu Y L, Yu W J. Manufacturing technology and application of laminated veneer lumber made with thicker veneers. China Wood Industry, 2016, 30(4): 13-16 (in Chinese)

113. Hu L, Chen Z L, Fu F. Comparison analysis on properties of fireretardant plywood made with Eucalyptus and Poplar wood. China Wood Industry, 2015, 29(3): 43-46 (in Chinese)

114. Tang J, Zao L C, Chen H Z, Chen Y J, Wang J L, Xiao S R, Cao Y. Comparisons of antioxidant activities for Eucalyptus leaf extracts with common antioxidants. Food Science and Technology, 2013, 38(8): 247-251 (in Chinese)

115. Yang Q L, Xie Y J, Tan X F, Zhang J, Huang Y F, Wu Z H. Extraction of unsaturated fatty acids from Eucalyptus leaves and its components. Chemistry and Industry of Forest Products, 2013, 33 (2): 113-117 (in Chinese)

116. Chen H Z, Huang J S, Wang J L, Yang J, Chen Y J, Xiao S R, Cao Y. Total polyphenol and antioxidant activities of 'Guanglin No.9' Eucalyptus leaves from different months. Science and Technology of Food Industry, 2013, 34(17): 56-59 (in Chinese)

117. Chen Y, Onken B, Chen H, Xiao S, Liu X, Driscoll M, Cao Y, Huang Q. Mechanism of longevity extension of Caenorhabditis elegans induced by pentagalloyl glucose isolated from eucalyptus leaves. Journal of Agricultural and Food Chemistry, 2014, 62(15): 3422-3431

118. Li G Y, Xu J M, Fan J X. Clinical Research Progress and Pharmacological Effect of Eucalyptus oil. Journal of Anhui Agricultural Sciences, 2014, 42(12): 3602-3603 (in Chinese)

119. Chen Y J, Wang J L, Ouyang W, Chen H Zh, Xiao S Y, Liu G, Cao Y, Huang Q R. Cellular antioxidant activities of polyphenols isolated from Eucalyptus leaves. Journal of Functional Foods, 2014, 2014(7): 737-745 